\title{
Household Life Cycle: The Case Of Customer Satisfaction In Restaurants
}

Cindy Erdis, University of South Africa (UNISA), South Africa

Michael du Toit, University of South Africa (UNISA), South Africa

\begin{abstract}
The restaurant industry is rife with customers experiencing unacceptable levels of customer service, resulting in many customers often deciding to take their patronage elsewhere. Marketing researchers have long been investigating the influence of family on customer behaviour and satisfaction, but very limited research has been done on the influence of the family structure on customer satisfaction in restaurants.

This article examines the influence of household life cycle on customer satisfaction in selected restaurants in the Tshwane area of Gauteng, South Africa. An empirical study was conducted with the aim of establishing if the stage in the household life cycle of restaurant patrons has an influence on the level of customer satisfaction experienced when visiting restaurants. A selfadministered survey was conducted whereby questionnaires were handed to restaurant patrons with the restaurant bill folder. Based on the research results, it was found that the stage in the household life cycle of restaurant patrons does indeed have an influence on how satisfied customers were with regard to certain aspects relating to customer service, which in turn influences their overall customer satisfaction. This is important for restaurants who want to retain customers based on their loyalty and to ultimately increase profitability.
\end{abstract}

Keywords: Lifecycle; Family; Consumer Behaviour; Satisfaction

\section{INTRODUCTION}

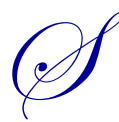

haping customer satisfaction is fundamental to the effective delivery of services. Product differentiation, increased customer retention and positive word-of-mouth communication are all potential benefits of the judgment and management of customer satisfaction levels. These benefits are important to organisations that operate in an increasingly competitive environment and need to differentiate themselves from their rivals. The services industry is characterized by remarkable growth, and companies are finding that they need to focus on service to keep up with rising customer expectations and to compete effectively (Zeithaml, Bitner, \& Gremler 2009, pp. 6-8).

Hoffman and Bateson (2006, pp. 76-77) purport that in a competitive industry such as the restaurant industry, one of the main keys to success and creating a competitive edge is providing customer service and developing compelling service experiences far superior to those offered by competitors.

Whilst previous research into customer satisfaction in restaurants has focused on individuals and couples, very little research has been conducted into the various family or household types with regard to satisfaction in restaurants. Sociologists and consumer researchers have long been attracted to the concept of the family or household life cycle as an influence on consumer behaviour (Parumasur \& Roberts-Lombard, 2012, p. 274). The concept of the family or household life cycle has evolved over the last thirty years and has undergone many changes, evolving from a unilateral theory of individual decision-making to a complex hybrid theory that involves both individual and joint decision-making (Fodness, 1992, p. 8) An important concept in household analysis is household life cycle analysis, which enables marketers to segment households in terms of a series of stages spanning the life course of a household unit. Households are defined as a domestic unit consisting of the members of a family who live together along with non-relatives, such as servants (thefreedictionary.com, 2013). 
The basic idea is that households pass through a predictable progression or series of stages which are defined by unique combinations of socioeconomic and or demographic variables. Research attempts to describe, understand, and predict how household members interact and influence one another in terms of individual and household buying. According to Diamond (2012, p. 93), the concept of the family life cycle assumes that the purchasing patterns of those within each stage or unit are somewhat similar for all types of products, including apparel, food, restaurant dining, and travel. Significant research has been conducted into the influence of various members of households on travel decisions (Fodness, 1992; Christina \& Sharon, 2002; Flurry \& Burns, 2005), but there is very little research on the influence of family or household life cycle on customer satisfaction in restaurants.

The question arises as to whether the stage in the household life cycle of a particular family has an influence on the level of customer satisfaction experienced by restaurant patrons. This article examines the influence of household life cycle on customer satisfaction in selected restaurants in the Tshwane area of Gauteng, South Africa. The research on which this article is based was conducted by means of an exploratory study with the aim of establishing if the stage in the household life cycle of restaurant patrons has an influence on the level of customer satisfaction experienced when visiting restaurants.

\section{LITERATURE REVIEW}

Customer satisfaction is one of the most researched areas in marketing, and the importance thereof cannot be overemphasised (Hoffman \& Bateson, 2006, pp. 302-303). The aim of excellent customer service is to achieve customer satisfaction and to ultimately create and maintain customer loyalty (Christopher et al., 2002, p. 58; Küster \& Villa, 2006, pp. 3-20; Xu, Goedegebuure, \& Van der Heijden, 2006, pp. 79-87).

Customer service has strategic importance and requires companies to continually enhance customer experience and satisfaction to deliver quality in a competitive marketplace (Spencer-Matthews \& Lawley, 2006, p. 218). Egan (2001, p. 96) refers to customer satisfaction as a "psychological process of evaluating perceived performance outcomes based on predetermined expectations." Customer satisfaction thus involves the customer's feelings that a product or service has met or exceeded expectations (Brink \& Berndt, 2008, p. 58).

Although organisations and managers may argue that customers are unreasonable at times, satisfying customers is not an impossible task and holds several valuable benefits for an organisation. The benefits include positive word-of-mouth, which often translates into new customers; the ability to insulate themselves from competitive pressures and even customers that are willing to pay a premium price and remain with an organisation that meets its needs rather than to take the risk of moving to a lower-priced service offering (Bateson \& Hoffman, 2006, p. 306). Word-of-mouth advertising for an organisation, such as a restaurant, is always necessary because both satisfied and dissatisfied customers will spread the word.

Customer satisfaction generally occurs if customers attach importance to the perceived value received. Customer satisfaction is thus closely linked to customer value. An organisation tries to make itself different from its competitors, based on the benefits that its products or services offer to its customers. In order for these benefits to be meaningful, the customer must perceive them to be meaningful. Some marketers believe that the only way an organisation can differentiate itself from its competitors is to deliver superior customer value (Cant, Brink, \& Brijball, 2006, p. 11; 34). Thus, if a restaurant wishes to offer superior value to its customers, it should provide better for customer needs than its competitors do (Erdis, 2010, p. 53). Customer value represents the impact that the supplier's offer has on the customer's own value chain. If the market offering delivers better performance, better perceived benefits or lower customer costs, then there is a clear added-value from the customer's perspective (Christopher et al., 2002, pp. 20-24). Accordingly, a restaurant that delivers quality food and service at a better price than its competitors delivers better value to its customers than its competitors.

According to Zeithaml et al. (2009, p. 103), customer satisfaction is influenced by situational and personal factors, service quality, product quality, and price, which ultimately affect customer loyalty. The aim of the research that this article is based on was to determine if one of these factors - namely, personal factors, with specific reference to the stage in the household or family lifecycle - has an influence on the level of customer satisfaction experienced in restaurants. 
Marketing scholars agree that one specific group that arguably has the greatest influence on consumer behaviour is the family or household group (Cant, 2010, p. 49; Kotler \& Keller, 2009, p. 33; Perumasur \& RobertsLombard, 2012, p. 27). Marketers often examine the attitudes and behaviour of the various household members who they believe to be the major decision-makers, while sometimes they also examine the attitudes and behaviours of the person most likely to be the main user of the particular product. As discussed earlier, marketers often use the household or family lifecycle to predict how family or household members interact with and influence one another in terms of individual or household buying behaviour.

The household lifecycle is a composite variable created by systematically combining commonly used demographic variables, such as marital status, the size of the household, and the age of the household members. Five stages in the traditional family lifecycle have been identified (Perumasur \& Roberts-Lombard, 2012, pp. 276-277) and their influence on the behaviour of customers thoroughly researched. Bachelorhood is the first stage where young single men and women have established households away from their parents. The next stage - namely, honeymooners - occurs after marriage and continues until the arrival of the couple's first child. Parenthood - the third stage - occurs with the arrival of the couple's first child, and this stage usually lasts longer than 20 years. Throughout this stage, the interrelationships of household members and the structure of the household gradually changes, with significant changes also occurring in the financial resources of the household. Post-parenthood, which occurs once the children leave the household, signifies a time for many parents to do all the things they were unable to do when their children lived at home, such as travelling and taking up hobbies. Post-parenthood is the fourth stage in the traditional family lifecycle. As customers, many people in the post-parenthood stage of the household lifecycle have much more disposable income to spend on themselves than when the children were living at home. The last stage - namely, dissolution - occurs with the death of one of the spouses.

\section{METHODOLOGY}

The research on which this article is based was conducted by means of quantitative exploratory research in the Tshwane area of Gauteng in South Africa. The primary objective of exploratory research is the provision of insights into, and the comprehension of, the problem confronting the researcher (Hair, Bush, \& Ortinau, 2003, p. 41). The data were collected by means of self-administered experience surveys, which are defined as those that attempt to tap the knowledge and experience of those familiar with the general subject being investigated (Churchill \& Brown, 2004, p. 94). During self-administered surveys, respondents are left on their own to complete questionnaires and there is no computer or interviewer present to assist them (Cant, 2005, p. 100). Organisations that generally use this method include airlines, hotels, and restaurants, which is why this form of survey was selected by the researcher as being suitable for the research at hand.

Self-administered interviews were selected for use in this study using a structured questionnaire. In the questionnaire, open-ended, as well as closed-ended questions, were used. The open-ended questions asked respondents to reply in their own words, whereas the closed-ended questions required respondents to choose between two or more answers (McDaniel \& Gates, 2003, pp. 295-296). Respondents were asked to rate certain factors of the exterior, interior, service, and food of the restaurant on a five-point Likert scale. The exterior physical variables measured were signage, parking, security, cleanliness, and attractiveness of store front.

The interior physical variables measured were atmosphere, décor, lighting, cleanliness of eating area, comfortability of furniture, and cleanliness of bathroom. Service variables surveyed measured were professionalism, friendliness, speed of service, product knowledge, handling of special requests or orders, reservation details correct, and time waited to be seated. Finally, the food variables included presentation, menu variety, and correctness of orders. These factors form the servicescape of a restaurant and are crucial to provide cues to the customer about the restaurant's service quality, as customers often rely on tangible cues or physical evidence to evaluate service (Brink \& Berndt, 2008, p. 83; Zeithaml et al., 2009, p. 313).

Due to the large amount of restaurants in the Tshwane Area of Gauteng, South Africa, a census was not feasible and a sample of the total population of restaurants was decided on for the survey. Ten restaurants were selected by means of convenience sampling and 30 patrons were targeted at each restaurant, resulting in a sample size of 300 respondents. 
Although an exploratory study was conducted and descriptive statistics adequate for the purpose of this study, it was decided by the researcher to conduct certain significance tests as well, due to the fact that a large number of respondents (namely, 292) completed the questionnaire. Often a researcher wants to go beyond describing the sample data to say something about the population from which the sample was drawn (Tustin, Ligtelm, Martins, \& Van Wyk, 2005, p. 559).

In other words, a researcher needs to make inferences about the population on the grounds of what has been observed from the sample. A basic tenet of statistical inference is that it is possible for numbers to be different in a mathematical sense but not significantly different in a statistical sense (McDaniel \& Gates, 2003, p. 413). These statistical differences are defined by the selected significance level. The smaller the chosen significance level, the smaller the degree of risk that the researcher will be willing to accept. The significance levels of 0.05 and 0.01 are used by most researchers when performing statistical tests. For the purpose of the research that this article is based on, a significance level of 0.05 was considered adequate.

The following statistical tests were used:

- Chi-square: This test is used when a set of observed frequencies is compared to a set of expected frequencies (Tustin et al., 2005, p. 609).

- $\quad$ Analysis of variance (ANOVA): This test is used for examining the differences in the mean values of the dependant variable associated with the effect of the controlled independent variables (Malhotra, 2004, p. 469). The ANOVA test calculates both a frequency and a p-value. A p-value of less than 0.05 is considered significant.

- $\quad$ Correlation analysis: This is the analysis of the degree to which changes in one variable are associated with changes in another (McDaniel \& Gates 2003, p. 448).

\section{RESULTS}

Figure 1 illustrates that most respondents were single, widowed, or divorced (34.06\%) with no children. Less than $40 \%$ of respondents had one or more children living at home. Having children in the household will influence the patron's choice of restaurant and overall customer satisfaction level, as not all restaurants cater for children in as far as menu selection and baby-changing facilities, for example.

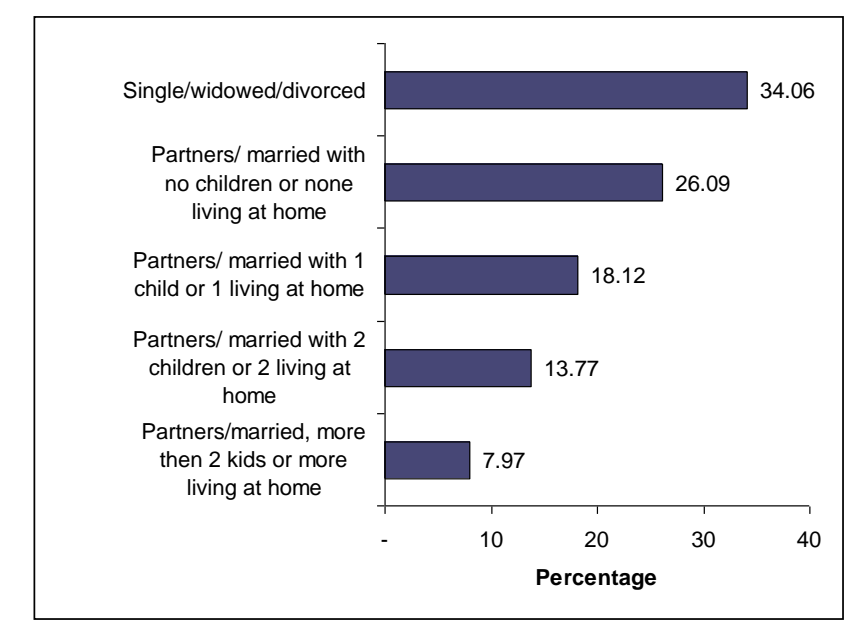

Figure 1: Family Structure of Respondents in the Sample $(\mathrm{N}=276)$

Figure 2 represents the mean scores on each of the exterior physical factors graphically. As can be seen from Figure 2, cleanliness and attractiveness are the highest rated exterior components (4.21 and 4.05, respectively), which could have a significant influence on the level of customer satisfaction experienced by restaurant patrons if the restaurants they patronise are in fact clean and attractive inside. Signage and parking received the lowest relative ratings (3.08 and 3.77). 


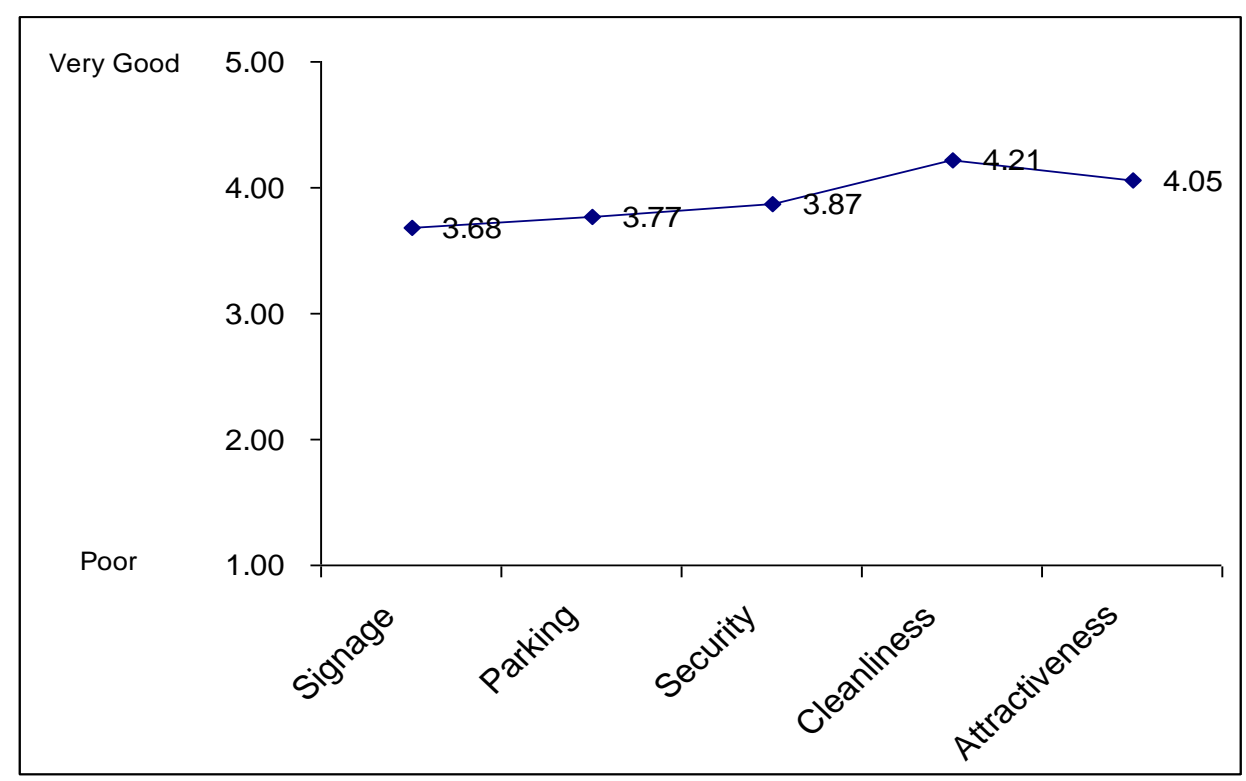

Figure 2: Mean Scores of the Ratings of the Factors of the Exterior (290 $\geq N \geq 288$ )

Factors of the interior rated by respondents included atmosphere, décor, lighting, cleanliness of the eating area, comfortability of the furniture, and cleanliness of the bathrooms. Figure 3 graphically represents the mean rating scores on the interior factors.

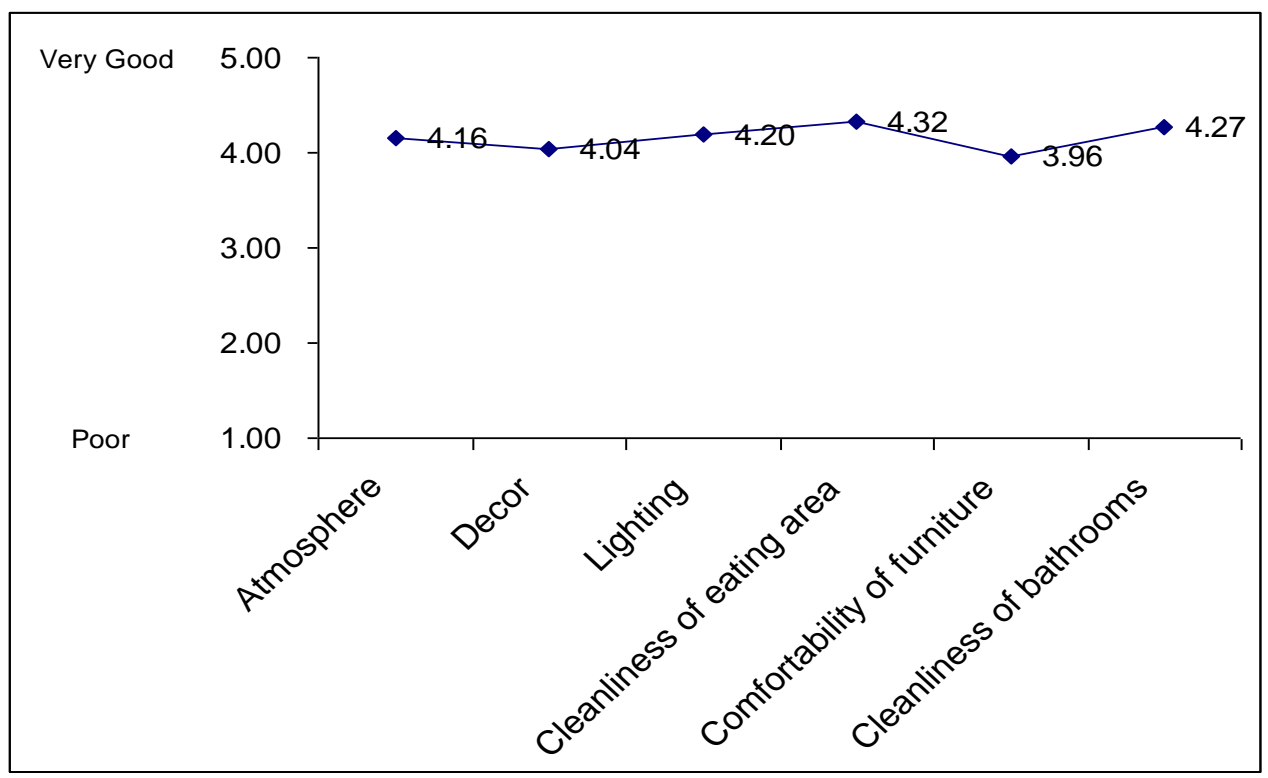

Figure 3: Mean Scores of the Ratings of the Factors of the Interior $(290 \geq N \geq 288)$

Once again, cleanliness rated best overall; both the cleanliness of the eating area (4.32) and the bathrooms (4.77) were rated very well. Atmosphere (4.16), décor (4.04), and lighting (4.20) were also rated well, while the furniture at the various restaurants was rated as not being particularly comfortable, receiving a relatively low rating of 3.96. Again, restaurant patrons that value cleanliness, atmosphere, and lighting as cues to the level of customer service could be very satisfied with the particular restaurant if it was perceived as clean, having atmosphere, and good lighting. 
Figure 4 represents the mean rating scores of the service aspects in graphic format.

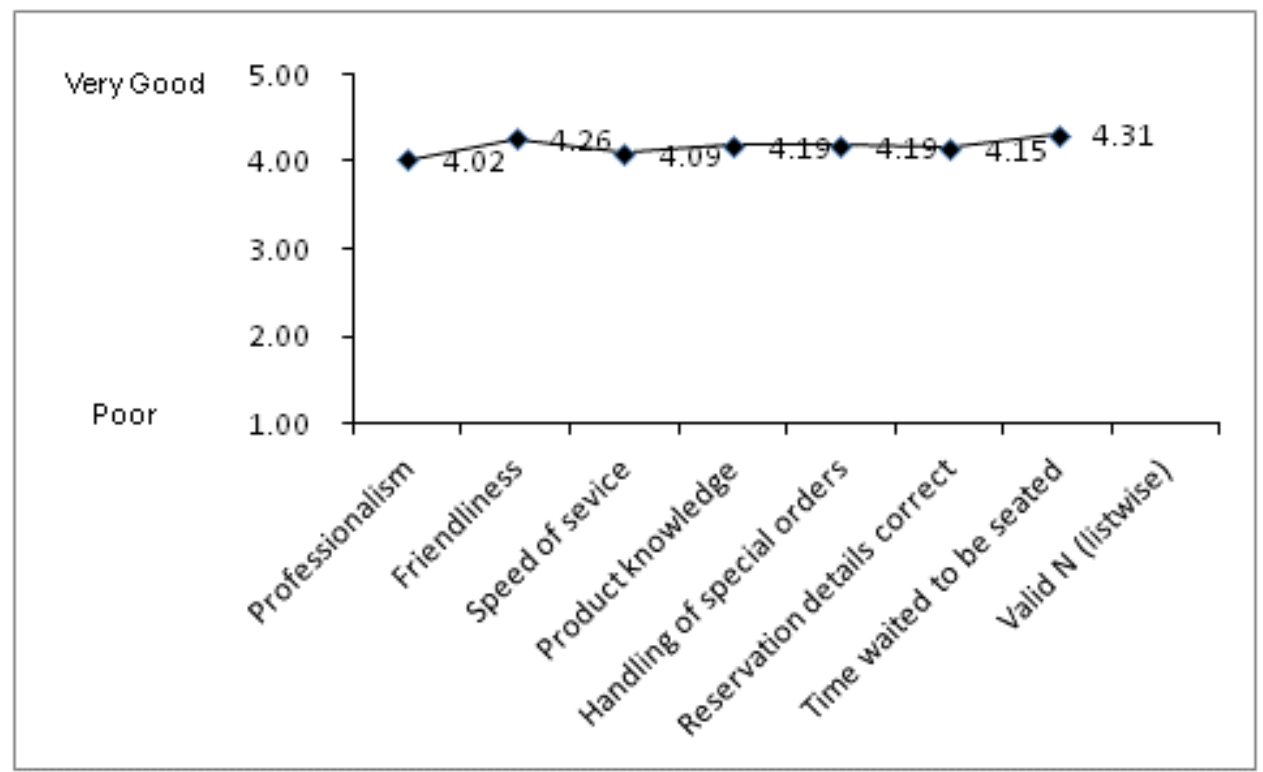

Figure 4: The Mean Rating Scores of the Service Aspects

Service factors were rated consistently high, all achieving above 4 out of 5 . The relative weaker rated areas are professionalism (4.02) and speed of service (4.09). Restaurant employees were rated as generally friendly (4.26), knowledgeable and willing to help (a score of 4.19 for both). With such consistently high scores, it can therefore be deduced that the respondents were generally satisfied with the service levels encountered.

The three food quality-related factors rated (presentation, menu variety, and correctness of the order) all received consistently high scores of above 4 out of 5, as presented in Figure 5.

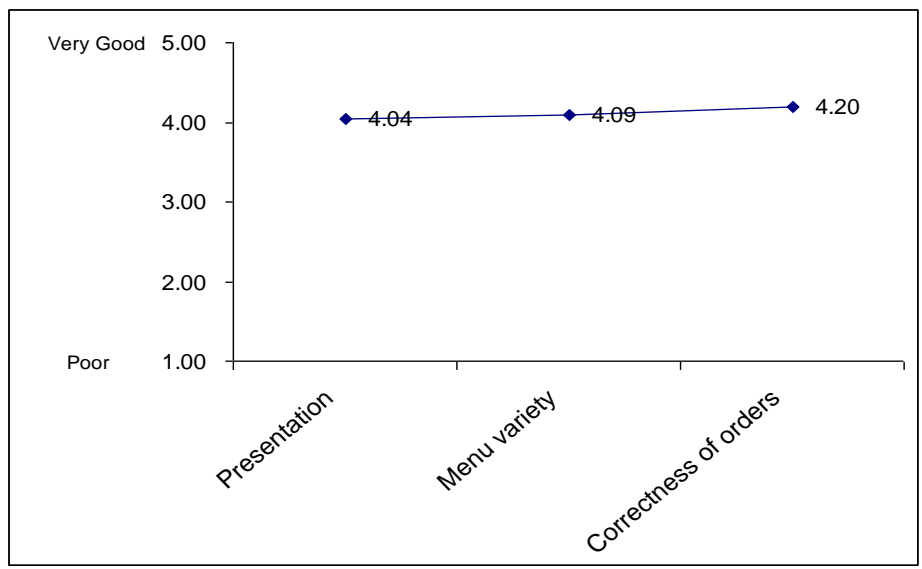

Figure 5: Mean Scores of the Ratings of the Food Related Factors $(283 \geq N \geq 282)$

As can be seen from Figure 5, the correctness of orders received the highest rating (4.20), followed by menu variety (4.09), and the presentation of food (4.04). It can therefore be deduced that the respondents had a favourable interaction with the service provider's product offering and were satisfied that their food orders were correctly received, that there was a variety of food offered on the menu, and that the food was well presented. 
ANOVA was used to compare the mean scores on each of the restaurant ratings for each family group. Table 1 indicates the associated F-values and significance values of the test.

Table 1: Comparisons of the Different Family Groups with Regard to the Restaurant Ratings

\begin{tabular}{|l|c|c|}
\hline \multicolumn{1}{|c|}{ Exterior Factors } & F & Sig. \\
\hline Signage & 0.28 & 0.89 \\
\hline Parking & 1.24 & 0.29 \\
\hline Security & 0.16 & 0.96 \\
\hline Cleanliness & 1.17 & 0.32 \\
\hline Attractiveness of exterior storefront & 0.71 & 0.59 \\
\hline \multicolumn{1}{|c|}{ Snter Factors } & 1.25 & Sig. \\
\hline Atmosphere Service Factors & 0.17 & 0.29 \\
\hline Decor & 1.58 & 0.95 \\
\hline Lighting & 0.32 & 0.18 \\
\hline Cleanliness of eating area & 1.36 & 0.87 \\
\hline Comfortability of furniture & 1.54 & 0.25 \\
\hline Cleanliness of bathrooms & F & 0.19 \\
\hline & 1.28 & Sig. \\
\hline Professionalism & 1.95 & 0.28 \\
\hline Friendliness & 0.26 & 0.10 \\
\hline Speed of service & 0.17 & 0.90 \\
\hline Product knowledge & 1.51 & 0.95 \\
\hline Handling of special requests/orders & 1.62 & 0.20 \\
\hline Reservation details correct & 1.80 & 0.17 \\
\hline Time waited to be seated & F & 0.13 \\
\hline Presentation & 3.57 & Sig. \\
\hline Menu variety & 2.52 & 0.01 \\
\hline Correctness of orders & 1.63 & 0.04 \\
\hline
\end{tabular}

The different family groups differ statistically significantly with regard to two factors related to the food of restaurants (highlighted in Table 1 above), including "presentation of the food" ( $p=0.01)$ and "menu variety" (0.04).

These findings are shown in more detail in Table 2, which presents the mean scores of each family group on each of these two factors. It appears that those respondents who are married with one child living at home are most negative toward the food presentation and the menu variety (mean $=3.66$ and 3.88 , respectively), as opposed to respondents with partners or who are married with no children or none living at home with mean scores of 4.14 and 4.24 for presentation and menu variety, respectively.

Table 2: Mean Scores of the Family Groups on the Ratings of Food Presentation and Menu Variety

\begin{tabular}{|l|c|c|}
\hline \multicolumn{1}{|c|}{ Family Groups } & Presentation & Menu Variety \\
\hline Single/widowed/divorced & 4.13 & 4.03 \\
\hline Partners/married with no children or none living at home & 4.14 & 4.24 \\
\hline Partners/married with 1 child or 1 living at home & 3.66 & 3.88 \\
\hline Partners/married with 2 children or 2 living at home & 4.00 & 4.03 \\
\hline Partners/married, more than 2 kids or more living at home & 4.27 & 4.41 \\
\hline
\end{tabular}

\section{CONCLUSION}

As seen from the literature study of this article, the importance of customer satisfaction can never be underestimated. The benefits of satisfied customers are important to organisations that operate in an increasingly competitive environment and that need to differentiate themselves from rivals. In a competitive industry, such as the restaurant industry, one of the main keys to success and creating a competitive edge is providing excellent customer service and developing service experiences far superior to those offered by competitors. Very limited research has been conducted into the various family or household lifecycle stages with regard to satisfaction in restaurants, which 
was the main focus of the research that this article is based on. The question arose as to whether the stage in the household lifecycle of a particular family has an influence on the level of customer satisfaction experienced by restaurant patrons.

Respondents were asked to rate certain factors of the exterior, interior, service, and food of the restaurant on a five-point Likert scale. The results of this study reveal that cleanliness and attractiveness are the highest rated exterior restaurant components which could have a significant influence on the level of customer satisfaction experienced by restaurant patrons. Signage and parking received the lowest relative ratings. With regard to factors of the interior of restaurants, cleanliness rated best overall. Atmosphere, décor, and lighting were also rated well. Restaurant patrons that value cleanliness, atmosphere, and lighting as cues to the level of customer service could be very satisfied with the particular restaurant if it as perceived as clean, having a pleasant atmosphere, and good lighting.

The service factors investigated were also rated consistently high. The three food quality-related factors rated all received consistently high scores of above 4 out of 5 . It can therefore be deduced that the respondents had a favourable interaction with the service provider's product offering, and were satisfied that their food orders were correctly received, that there was a variety of food on offer on the menu, and that the food was well presented.

ANOVA was used to compare the mean scores on each of the restaurant ratings for each family group. The family groups differ statistically significantly with regard to two factors related to the food of restaurants, including "presentation of the food" and "menu variety." It appears that those respondents who are married with one child living at home are most negative toward the food presentation and the menu variety, as opposed to respondents with partners or who are married with no children or none living at home.

Limitations of the research include that it was conducted only in the Tshwane area of Gauteng and therefore research can further be conducted into other areas in South Africa. Further research into household or family lifecycle, and the influence thereof on customer satisfaction in restaurants, will serve to clarify the extent to which factors, such as both internal and external, of a restaurant, service factors, and food serve as cues to families or households in varying stages of the lifecycle with regard to customer satisfaction.

\section{AUTHOR INFORMATION}

Cindy Erdis is a senior lecturer at the University of South Africa (UNISA). Her main areas of interest are CRM, services marketing, and retail management. She has contributed to a number of academic works on marketing and retail related topics. E-mail: erdisc@ unisa.ac.za (Corresponding author)

Michael du Toit is a senior lecturer at the University of South Africa (UNISA). His areas of interest include branding and personal selling, as well as the facilitation of learning in the online environment. He has contributed to various academic books on marketing related topics. E-mail: dtoitm3@unisa.ac.za

\section{REFERENCES}

1. Brink, A., \& Berndt, A. (2008). Relationship marketing and customer relationship management and customer service. Landsdowne: Juta.

2. $\quad$ Cant, M. C. (2005). Marketing research ( $2^{\text {nd }}$ ed.). Claremont: New Africa Education.

3. Christina, K. C. L., \& Sharon, E. B. (2002). Family structure and influence in family decision making. Journal of Consumer Marketing, 19(1), 24-41.

4. Christopher, M., Payne, A., \& Ballantyne, D. (2002). Relationship marketing: Creating stakeholder value. Oxford: Butterworth-Heinemann.

5. Erdis, C. (2010). Investigating customer service in selected restaurants in Tshwane - An exploratory study. (Unpublished MCom dissertation). Unisa.

6. Flurry, L. A., \& Burns, A. C. (2005). Children's influence in purchase decisions: A social power theory approach. Journal of Business Research, 58, 593-601. 
7. Fodness, D. (1992). The impact of family life cycle on the vacation decision-making process. Journal of travel research, $31,8$.

8. Hair, J. F., Bush, R. P., \& Ortinau, D. J. (2003). Marketing research: Within a changing information environment. New York: McGraw-Hill Irwin.

9. Grönroos, C. (2000). Service management and marketing- A customer relationship management approach $\left(2^{\text {nd }}\right.$ ed.). Chichester: Wiley.

10. McDaniel, C., \& Gates, R. (2003). Marketing research essentials $\left(4^{\text {th }}\right.$ ed.). Cincinatti, Ohio: South Western College.

11. Parumasur, S. B., \& Roberts-Lombard, M. (2012). Consumer behaviour (2 $2^{\text {nd }}$ ed.). Cape Town: Juta.

12. thefreedictionary.com/households (2013). Date of access: 28 October 2013.

13. Zeithaml, V.A., Bitner, M. J., \& Gremler, D. D. (2009). Services marketing - integrating consumer focus across the firm. New York: McGraw-Hill.

14. Diamond, J. (2012). Retail buying $\left(9^{\text {th }}\right.$ ed.). New Jersey: Pearson.

15. Egan, J. (2001). Relationship marketing - exploring relational strategies in marketing ( $1^{\text {st }}$ ed.). Pearson: Edinburgh Gate.

16. Hoffman, K. D., \& Bateson, J. E. G. (2006). Services marketing: concepts, strategies and cases ( ${ }^{\text {rd }}$ ed.). Mason, Ohio: Thompson South-Western

17. Kotler, P., \& Keller, K. L. (2006). Marketing management $\left(12^{\text {th }}\right.$ ed.). Upper Saddle River: Pearson Prentice Hall.

18. Kuster, I., \& Villa, N. (2006). Relational strategies in the textile sector: Internet use. Journal of Relationship Marketing, 5(4), 3-20.

19. Xu, Y., Goedebuure, R., \& Van der Heiden, B. (2006). Customer perception, customer satisfaction and customer loyalty within the Chinese securities business: Towards a mediation model for predicting customer behaviour. Journal of Relationship Marketing, 5(4), 79-87. 
NOTES 